\title{
HUBUNGAN SKOR SOFA DENGAN LAMA RAWAT INAP PASIEN SEPSIS PASCA LAPARATOMI DI ICU PERIODE JULI 2012 - SEPTEMBER 2013
}

\author{
${ }^{1}$ Tifany Tewuh \\ ${ }^{2}$ Diana Lalenoh \\ ${ }^{2}$ Lucky Kumaat
}

\author{
${ }^{1}$ Kandidat Skripsi Fakultas Kedokteran Universitas Sam Ratulangi Manado \\ ${ }^{2}$ Bagian Anestesiologi Fakultas Kedokteran Universitas Sam Ratulangi Manado
}

\begin{abstract}
Sofa score is one of the assessments used in ICU. Sofa score can help to see organ dysfunction or organ failure during treatment and can be used to predict the prognosis of patients treated in ICU. Aim: To determine the relationship of sofa score with length of stay patients septic post laparatomy in ICU. Methods: This study is a retrospective analytic study with collection data of sofa score patients septic post laparatomy in ICU RSUP Prof. R D. Kandou period July 2012-September 2013.Data were evaluated and analyzed to see the relationship with length of stay. Result: These results by using the spearman correlation test showed significance value $\mathrm{p}=0,557$ ( $\mathrm{p}>0,05)$. Conclusions: No relationship between the sofa score with length of stay patients septic post laparatomy in ICU because of less number of samples and a short period study.
\end{abstract}

Keywords: sofa score, length of stay, septic post laparatomy.

\begin{abstract}
Abstrak: Skor Sofa adalah salah satu penilaian yang digunakan di ICU. Skor Sofa dapat membantu untuk melihat disfungsi organ atau gagal organ selama perawatan dan dapat digunakan untuk memprediksikan prognosis dari pasien yang dirawat di ICU. Tujuan: Mengetahui hubungan Skor Sofa dengan lama rawat inap pasien sepsis post laparatomi di ICU. Metode: Penelitian ini merupakan penelitian analitik retrospektif dengan pengumpulan data skor sofa pasien sepsis post laparatomi yang dirawat di ICU RSUP Prof. DR. R. D. Kandou periode Juli 2012 - September 2013. Data dievaluasi dan dianalisis untuk melihat hubungannya dengan lama rawat inap. Hasil: Hasil penelitian ini dengan menggunakan uji korelasi spearman menunjukkan nilai signifikasi $\mathrm{p}=0,557(\mathrm{p}>0,05)$. Simpulan: Tidak didapatkan hubungan antara skor sofa dengan lama rawat inap pasien sepsis post laparatomi di ICU karena jumlah sampel yang kurang dan periode penelitian yang singkat.
\end{abstract}

Kata Kunci: skor sofa, lama rawat inap, sepsis post laparatomi.

Pada saat ini tersedia beberapa model berupa sistem penilaian yang dapat digunakan untuk memperkirakan mortalitas pasien di ICU. Beberapa sistem penilaian diantaranyaAcute Physiology and Chronic Health Evaluation (APACHE), Simplified Acute Physiology Score (SAPS), Mortality Probability Models (MPM), Sequential Organ Failure Assassment (SOFA), Multi Organ Dysfunction Score (MODS), dan
Logistic Organ Dysfunction Score (LODS), yang dinilai dan dihitung pada 24 jam pertama pasien dirawat di ICU. ${ }^{1}$

Salah satu sistem nilai yang lebih sederhana yang dikembangkan oleh kelompok kerja dari European Society of Intensive Care Medicine yaitu Sequential Organ Failure Assassment Score (Skor SOFA) yang menilai enam sistem organ dari 0-4 derajat kegagalan organ pada pasien- 
pasien yang dirawat di ICU. Selain itu, keakuratan dan ketepatan dari penilaian Skor SOFA sudah diakui baik oleh sejumlah klinisi. Parameter yang dihitung dalam Skor SOFA meliputi organ respirasi, renal, hepatik, kardiovaskular, hematologi,dan GCS. ${ }^{1,2}$

Skor SOFA dapat membantu untuk melihat disfungsi organ atau gagal organ selama perawatan dan dapat digunakan untuk memprediksikan prognosis dari pasien yang dirawat di ICU. Tujuan penelitian ini adalah untuk mengetahui hubungan skor sofa dengan lama rawat inap pasien sepsis post laparatomi di ICU.

\section{METODE}

Penelitian ini adalah penelitian analitik retrospektif dengan pengumpulan data skor SOFA pasien sepsis post laparatomi yang dirawat di ICU RSUP Prof. DR. R. D. Kandou periode Juli 2012-September 2013. Data dievaluasi dan dianalisis untuk melihat hubungannya dengan lama rawat inap.

Populasi penelitian adalah seluruh pasien di Ruang ICU RSU Prof. DR. R. D. Kandou Manado. Sampel penelitian adalah pasien sepsis post laparatomi yang dirawat di ICU periode Juli 2012 - September 2013.

Bahan penelitian berupa data sekunder yang diperoleh dari catatan rekam medik pasien sepsis post laparatomi yang dirawat di Ruang ICU RSU Prof. Dr. R. D. Kandou Manado periode Juli 2012-September 2013. Analisis data diolah menggunakan SPSS untuk mengetahui korelasi variabel penelitian. Uji statistik dilakukan dengan spearman correlation. Hubungan dinyatakan bermakna jika didapatkan $\mathrm{p}<0,05$. Semua analisis dilakukan dengan bantuan komputer menggunakan software SPSS 18.0.

\section{HASIL}

Dari perhitungan statistik didapatkan jumlah sampel 36, namun karena keterbatasan waktu dan kriteria maka saat ini didapatkan 9 sampel penelitian.

Tabel 1 Menunjukkan data karakteristik demografi, dimana umur dengan nilai terendah 18 tahun dan tertinggi 57 tahun sedangkan rata-rata keseluruhan sampel 44,56 dan simpangan baku untuk umur adalah 13,097. Skor sofa dengan nilai terendah 0 dan nilai tertinggi 7 sedangkan rata-rata keseluruhan sampel 3,11 dan simpangan baku 3,395.Pada lama rawat inap dengan nilai terendah 1 hari dan tertinggi 11 hari. Rata-rata keseluruhan sampel 5,44 dan simpangan baku untuk lama rawat inap adalah 3,395.

Pada Gambar 1 dapat dilihat distribusi sampel menurut jenis kelamin, dari 9 sampel jumlah laki-laki adalah 5 orang(55,56\%) dan perempuan 4 orang $(44,44 \%)$.

Tabel 2 Menunjukkan bahwa perbandingan lama rawat inap antara laki-laki dan perempuan dimana laki-laki memilki nilai rerata 5 hari dengan nilai terendah 2 hari dan nilai tertinggi 8 hari, sedangkan perempuan memiliki nilai rerata 6 hari dengan nilai terendah 1 hari dan nilai tertinggi 11 hari.

Tabel 3 Menunjukkan bahwa penderita sepsis post laparatomi yang paling banyak berada pada kelompok umur 51 sampai 60 tahun yaitu berjumlah 4 penderita atau 44,5\% dari keseluruhan subyek penelitian, selanjutnya kelompok umur 41 sampai 50 tahun berjumlah 3 penderita (33,3\%), sisanya 2 penderita (22,2\%) berada pada kelompok umur kurang dari 30 tahun.

Tabel 1. Data karakteristik demografi (Umur, skor sofa dan lama rawat inap)

\begin{tabular}{cccccc}
\hline Variabel & N & Nilai Terendah & Nilai Tertinggi & Rerata & Simpangan Baku \\
\hline Umur ( Tahun) & 9 & 18 & 57 & 44,56 & 13,097 \\
Skor Sofa & 9 & 0 & 7 & 3,11 & 2,205 \\
Lama Rawat & 9 & 1 & 11 & 5,44 & 3,395 \\
Inap (Hari) & & & & \\
\hline
\end{tabular}




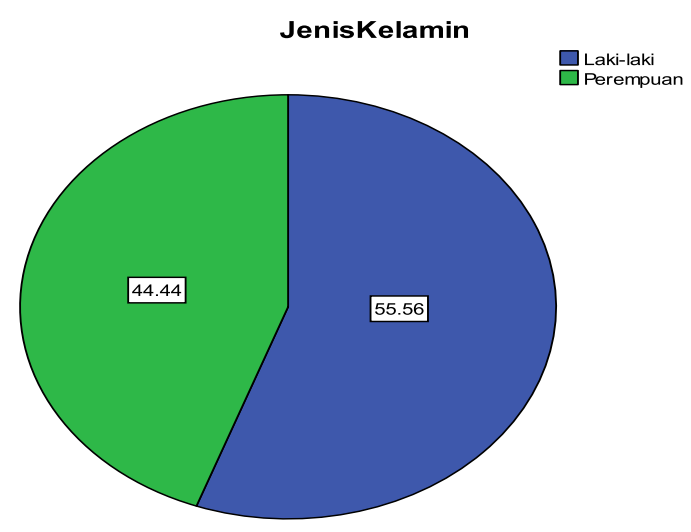

Gambar 1. Bagan distribusi sampel menurut jenis kelamin.

Tabel 2. Lama rawat menurut jenis kelamin

\begin{tabular}{ccccc}
\hline $\begin{array}{c}\text { Jenis } \\
\text { Kelamin }\end{array}$ & Frekuensi & $\begin{array}{c}\text { Nilai } \\
\text { terendah }\end{array}$ & $\begin{array}{c}\text { Nilai } \\
\text { tertinggi }\end{array}$ & Rerata \\
\hline $\begin{array}{c}\text { Laki-laki } \\
\text { Perempuan }\end{array}$ & 5 & 2 & 8 & 5 \\
& 4 & 1 & 11 & 6 \\
\hline
\end{tabular}

Tabel 3. Distribusi subyek menurut umur

\begin{tabular}{ccc}
\hline Umur & Jumlah & $\mathbf{\%}$ \\
\hline$<30$ & 2 & 22,2 \\
$30-40$ & 0 & 0 \\
$41-50$ & 3 & 33,3 \\
$51-60$ & 4 & 44,4 \\
\hline Total & $\mathbf{9}$ & $\mathbf{1 0 0}$ \\
\hline
\end{tabular}

Tabel 4. Analisis hubungan antara sub-variabel skor sofa dengan lama rawat inap pasien sepsis post laparatomi di ICU

\begin{tabular}{lccc}
\hline $\begin{array}{l}\text { Sub-variabel } \\
\text { Skor Sofa }\end{array}$ & $\mathbf{n}$ & $\mathbf{r}$ & $\mathbf{p}$ \\
\hline Respirasi & 9 & 0,218 & 0,572 \\
Koagulasi & 9 & $-0,070$ & 0,858 \\
Hepar & 9 & $-0,560$ & 0,117 \\
Kardiovaskular & 9 & 0,280 & 0,466 \\
Neurologi & 9 & 0,280 & 0,466 \\
Ginjal & 9 & 0,187 & 0,631 \\
\hline
\end{tabular}

Tabel 4 Menunjukkan bahwa setelah dilakukan uji korelasi spearman maka didapatkan nilai signifikasi untuk respirasi $\mathrm{p}=0,572$, koagulasi $\mathrm{p}=0,858$, hepar $\mathrm{p}=0,117$, kardiovaskular $\mathrm{p}=0,466$, neurologi $\mathrm{p}=0,466$, dan ginjal $\mathrm{p}=0,631$.
Tabel 5. Analisis hubungan skor sofa dengan lama rawat inap pasien sepsis post laparatomi di ICU

\begin{tabular}{lccccc}
\hline $\begin{array}{c}\text { Variab } \\
\text { el }\end{array}$ & $\begin{array}{c}\text { Rerat } \\
\text { a }\end{array}$ & $\begin{array}{c}\text { Simpanga } \\
\text { n Baku }\end{array}$ & n & r & P \\
\hline Skor & 3,11 & 2,205 & & & \\
$\begin{array}{l}\text { Sofa } \\
\text { Lama }\end{array}$ & & & & & \\
$\begin{array}{l}\text { Rawat } \\
\text { Inap }\end{array}$ & 5,44 & 3,395 & & 7 & 7 \\
(hari) & & & & & \\
\hline
\end{tabular}

Tabel 5 Menunjukkan bahwa setelah dilakukan uji korelasi spearman maka didapatkan nilai signifikasi 0,557.

\section{BAHASAN}

Pada analisis data rekam medik tidak terlihat adanya hubungan antara skor sofa dengan lama rawat inap pasien sepsis post laparatomi berdasarkan uji statistik yang dilakukan dengan uji korelasi spearman (Tabel 4). Signifikasi yang ditunjukkan pada Tabel 4 menunjukkan uji yang dilakukan dengan dua sisi (2-tailed) sebagai dasar pengambilan keputusan yaitu jika probabilitas $>0,05$ maka hipotesis nihil $\left(\mathrm{H}_{0}\right)$ diterima atau gagal ditolak dan jika probabilitas $<0,05$ maka $\mathrm{H}_{0}$ ditolak.Dari hasil penelitian yang didapatkan ini ternyata berbeda dengan hasil penelitian yang dilakukan oleh Aris Sunaryo dkk. Berdasarkan uji statistik yang dilakukan oleh Aris Sunaryo dkk didapatkan lama perawatan menunjukkan perbedaan yang bermakna yaitu $\mathrm{p}=0,004 .{ }^{1}$ Berbeda dengan penelitian ini, dimana penulis mendapatkan bahwa angka signifikasi skor sofa dengan lama rawat inap pasien sepsis post laparatomi adalah $\mathrm{p}=0,557$. Hal ini berarti tidak ada hubungan yang signifikan antara skor sofa dengan lama rawat inap pasien sepsis post laparatomi.

Sejumlah parameter fisiologi digunakan untuk mendefinisikan disfungsi organ, yaitu paru-paru, kardiovaskular, ginjal, hati, hematologi, dan sistem saraf pusat. Disfungsi organ disebabkan karena tidak adekuatnya pasokan oksigen untuk memenuhi kebutuhan metabolisme, jika 
keadaan ini berlangsung lama maka akan berakibat pada kegagalan beberapa organ. ${ }^{1}$

Menurut Priyanto dkk, kelainan intrinsik fungsi jantung ditemukan pada 40\% pasien sepsis meskipun curah jantung pada keadaan sepsis berada dalam batas normal atau bahkan meningkat. Gangguan fungsi jantung pada keadaan sepsis dapat meningkatkan resiko terjadinya kematian. Hal ini sejalan dengan penelitian yang dilakukan oleh Sunaryo dkk, dimana setiap kenaikan sebesar 1 unit variabel kardiovasular akan meningkatkan mortalitas pasien sebesar 3,956\%, dengan nilai keakuratannya sebesar 90,15\%. Penurunan curah jantung pada keadaan sepsis yang disertai gangguan respon intrinsik organ kardiovaskular bermanifestasi pada timbulnya gangguan hemodinamik yang ditandai oleh penurunan tonus pembuluh darah perifer, gangguan perfusi sistem organ dan terjadinya penurunan pompa jantung yang diakibatkan oleh dilatasi ruang-ruang jantung disertai gangguan compliance (diastolik). Hal ini dapat mempengaruhi dalam penilaian skor sofa. ${ }^{1,3}$

Pada penelitian yang dilakukan oleh Suliarni, parameter koagulasi dapat mempengaruhi dalam penilaian skor sofa. Pada penelitiannya trombosit pada pasien-pasien sepsis,secara bermakna lebih rendah dibanding dengan subyek normal $(p<0,001)$, hal ini mungkin bahwa pada pasien-pasien sepsis tersebut ada tendensi untuk menjurus ke arah DIC, walaupun jumlah trombosit rata-rata dari pasien tersebut masih dalam batas normal. ${ }^{4}$

Pada gangguan fungsi ginjal dapat terjadi produksi urin yang normal maupun berkurang. Peningkatan kreatinin $>0,3 \mathrm{mg} / \mathrm{dl}$ dari nilai sebelumnya atau peningkatan $>50 \%$ atau oliguri $<0,5 \mathrm{cc} / \mathrm{kgbb} / \mathrm{jam}$ lebih dari 6 jam menandakan gangguan ginjal akut. $^{5}$

Selain dari parameter pemeriksaan skor sofa faktor usia juga dapat mempengaruhi lama rawat inap. Pada orang yang usianya semakin tua lebih rentan terkena infeksi karena proses perubahan tubuh, menurunnya fungsi organ-organ dan sistem imun. ${ }^{6}$

Pada penelitian ini hasil yang didapat tidak sesuai dengan penlitian sebelumnya. Hal ini kemungkinan disebabkan karena pada penelitian ini mungkin jumlah sampel yang kurang, periode penelitian yang singkat, ataupun tidak ada data penyakit kronis penderita yang mungkin mempengaruhi penilaian skor sofa, sehingga pada penelitian ini tidak didapatkan hubungan antara skor sofa dengan lama rawat inap.

\section{SIMPULAN}

Dari hasil penelitian hubungan skor sofa dengan lama rawat inap pasien sepsis post laparatomi di ICU disimpulkan bahwa tidak terdapat hubungan antara skor sofa dengan lama rawat inap pasien sepsis post laparatomi di ICU karena jumlah sampel yang kurang dan periode penelitian yang singkat.

\section{DAFTAR PUSTAKA}

1. Sunaryo A, Redjeki IS, Bisri T. Perbandingan Validasi APACHE II dan Skor SOFA untuk Memperkirakan Mortalitas Pasien yang Dirawat di Ruang Perwatan Intensif. Di akses pada http://perdici.org/wp-

content/uploads/mkti/2012-02-01/mkti20120201-011020.pdf tanggal 1 Januari 2012.

2. Vincent JL, Moreno R, Takala J, Willatts S, De Mendoca A, Bruining $\mathrm{H}$, dkk. The SOFA (Sepsis-related Organ Failure Assessment) score to describe organ dysfunction/failure. Intensif Care Med 1996;22:707-10.

3. Priyantoro K, Lardo S, Yuniadi Y. Cardiac Dysfunction Due to Sepsis. Jurnal kardiologi Indonesia. 2013;31:185

4. Suliarni. Aktifitas Faktor VII pada sepsis. USU digital. 2003:38

5. Napitupulu HH. Sepsis Sepsis. Anestesia dan Critical Care. 2010;28:53.

6. Parlindungan F, Sembiring E, Marpaung S, Ginting F, Kembaren T, Rahimi A,dkk. Sepsis pada lansia. Divisi Penyakit Tropik dan Infeksi. Departemen Ilmu Penyakit Dalam FK USU. 2012:1 